\title{
Studies on subalpine forests of Hamta Pass area in Himachal Pradesh, India with a focus on Betula utilis populations
}

\author{
Khashti Dasila ${ }^{1}$, S. S. Samant ${ }^{2, *}$ and Anita Pandey ${ }^{3}$ \\ ${ }^{1}$ Centre for Environmental Assessment and Climate Change, G.B. Pant National Institute of Himalayan Environment, Kosi-Katarmal, \\ Almora 263 643, India \\ ${ }^{2}$ Himalayan Forest Research Institute, Conifer Campus, Panthaghati, Shimla 171 013, India \\ ${ }^{3}$ Department of Biotechnology, Graphic Era (Deemed to be University), Bell Road, Clement Town, Dehradun 248 002, India
}

\begin{abstract}
The present study was conducted in Hamta Pass area of Kullu district, Himachal Pradesh, India with a focus on Betula utilis populations. Totally 16 populations of $B$. utilis representing four habitats and three aspects were studied. The maximum sites were represented by moist and moist, shaded habitats with northwestern aspect. Totally 188 plant species representing trees, shrubs and herbs were recorded. Acer acuminatum, Abies pindrow, Prunus cornuta and Quercus semecarpifolia were the major associated species of $B$. utilis in the subalpine zone of Hamta Pass. Based on importance value index five tree communities, namely $A$. acuminatum, $A$. pindrow, B. utilis, $Q$. semecarpifolia and $B$. utilis-P. cornuta mixed were identified. Among the communities, total density of trees, shrubs and herbs was recorded from 160 to 270 , 300 to 515 and 21 to 33 individuals $m^{-2}$ respectively. The total basal area recorded was $6.94-42.10 \mathrm{~m}^{2} \mathrm{ha}^{-1}$, species richness 15-127, and species diversity for trees 0.4-0.9, shrubs $0.0-2.1$ and herbs $1.7-4.2$. The density and regeneration (i.e. seedlings and saplings) of $B$. utilis in most of the populations revealed that this species will continue to grow in the area. However, continued anthropogenic activities, climate change and other factors may cause population depletion in the study area.
\end{abstract}

Keywords: Betula utilis, regeneration, species diversity, species richness, subalpine forests, total basal area.

\section{Introduction}

THE unique topography, climatic conditions, diverse habitats and large altitudinal range of the Indian Himalaya Region (IHR) constitute an important part in global biodiversity hotspots ${ }^{1}$. The mountain ecosystem harbours diverse biological communities and a high level of endemism ${ }^{2}$. The Northwestern Himalaya is irregular and disturbed by valleys and plateaus with great floristic diversity due to altitudinal variations ${ }^{3}$. There is exorbitant

\footnotetext{
*For correspondence. (e-mail: dir.hfri@icfre.org)
}

biodiversity in the Himalayan ecosystems, which are recognized for their provisioning, cultural, regulating and supporting services to both upland and lowland inhabitants ${ }^{4}$. However, due to various anthropogenic and changing climate scenarios, these ecosystems and the services provided by them are being severely affected, causing loss of biodiversity and reduction in ecosystem services. Subalpine forests share the elements of high alpine and low temperate zones in the Himalaya, as they form a transition zone between temperate forest and alpine meadows ${ }^{5}$. The biodiversity components (i.e. vegetation structure, composition and function) of the subalpine and alpine ecosystems are severely affected by heavy grazing, overexploitation of woody species for fuel by herdsmen and non-timber forest products (NTFPs), including medicinal plants ${ }^{6}$.

The rapid geo-climatic variations are the basis of different environmental gradients and result in vegetation and diverse plant community types ${ }^{7}$. Habitat loss, fragmentation, overexploitation, alien species invasion and global climate change are the threats to biodiversity and the ecosystem ${ }^{8}$. These threats are also responsible for the decreasing trend of native species, upward shifting of species and the opportunity for proliferation of invasive and exotic species with low economic value ${ }^{9}$. Other than anthropogenic and climatic impacts, topographical factors (i.e. altitude, habitat and aspect) control the distribution patterns of vegetation in the Himalayan ecosystems ${ }^{10}$. In the current scenario, subalpine forests are the subject of interest for many researchers and are being studied for the impact of global climate change worldwide.

Betula utilis D. Don (bhojpatra or Himalayan silver birch) is a broadleaved, deciduous, ecologically and economically important tree. It represents one of the dominant species of the Himalayan treeline. The high freezing tolerance features enables this species to form a treeline in the Himalaya ${ }^{11}$. This species is found in major association with Abies pindrow, Abies spectabilis, Quercus semecarpifolia, Prunus cornuta, Acer acuminatum, Sorbus foliolosa, Pinus wallichiana and Rhododendron campanulatum. The bark is the characteristic feature of B. utilis 


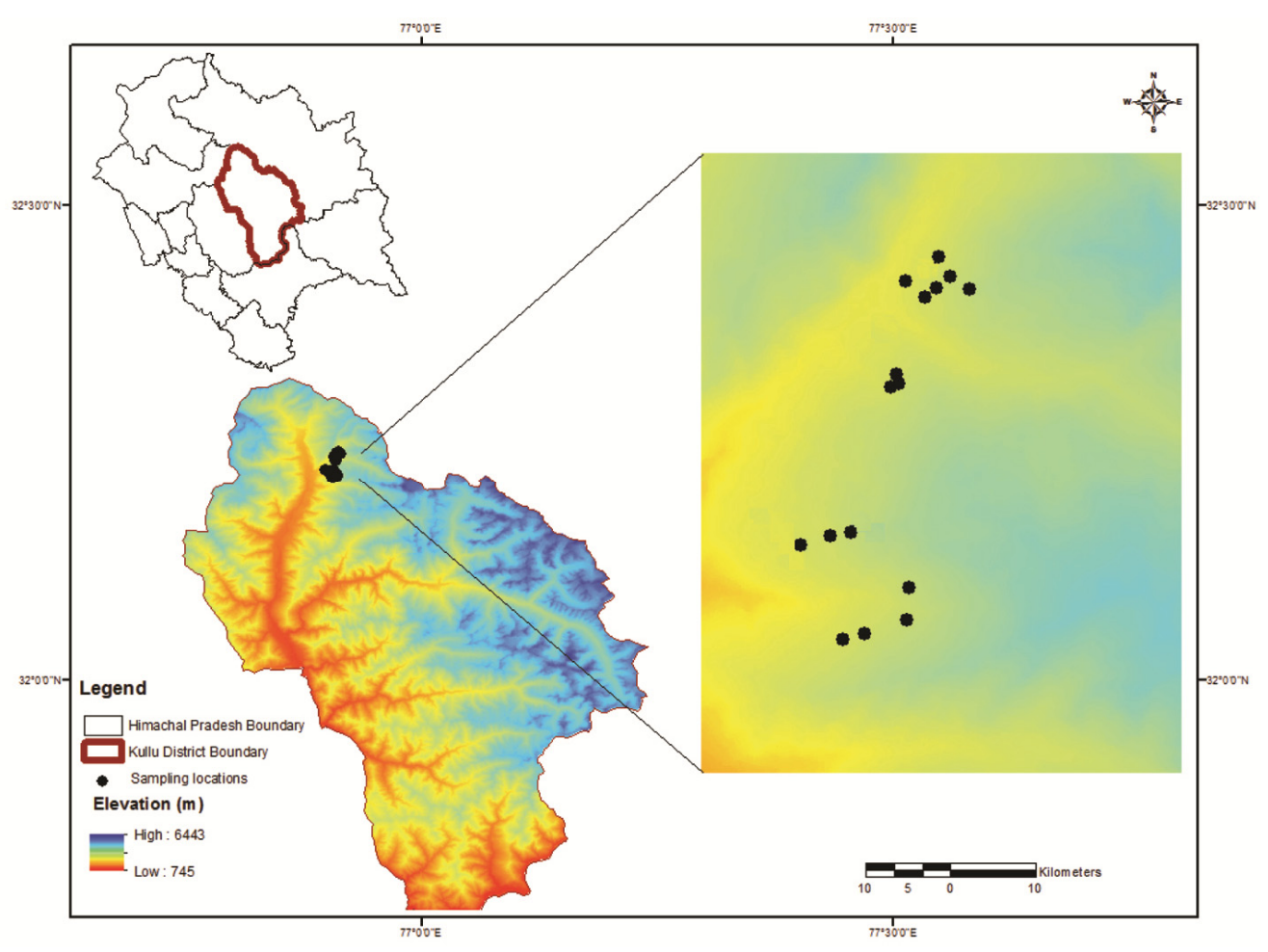

Figure 1. Map showing the sites of Betula utilis populations in Himachal Pradesh, India.

due to its shining, reddish-white appearance having both ethnobotanical $^{12,13}$ and phytochemical properties like anti-cancerous, anti-HIV, antioxidant, antimicrobial and anti-fertility activities ${ }^{14-16}$

In general, systematic studies, i.e. qualitative and quantitative assessment of subalpine forests, including B. utilis have been carried out by various workers ${ }^{17-33}$ in the IHR. However, focused studies on B. utilis populations have not been carried out so far. Therefore, in view of the various anthropogenic pressures and changing climate scenario, assessment of floristic diversity of the subalpine forests, including $B$. utilis populations becomes utmost important.

\section{Materials and methods}

\section{Study area}

The present study was conducted in Hamta Pass area of Northwestern Himalaya of Kullu district, Himachal Pradesh, India (Figure 1). The subalpine zone in the present study area is dominated by broadleaved deciduous species (i.e. Q. semecarpifolia, P. cornuta, A. Acuminatum, S. foliolosa, Corylus jacquemontii and $B$. utilis) and evergreen coniferous species (i.e. A. pindrow, A. spectabilis and $P$. wallichiana). The dominant shrub species are Rhododendron campanulatum, Rhododendron anthopogon, Salix denticulata, Rosa macrophylla, Rosa sericea, Smilax vaginata, Spiraea bella, Juniperus indica and Lonicera spp.

\section{Vegetation assessment in B. utilis forests}

Extensive and intensive field surveys were conducted during July and August 2018. For the sampling of floristic diversity of $B$. utilis forests, each accessible habitat and aspect was selected and assessed. Based on physical characters and dominance of the vegetation, habitats were identified. Site characteristics, i.e. latitude, longitude, altitude, slope and aspect of each site representing B. utilis populations were recorded with the help of global positioning system (GPS), Abney level and compass. For quantitative assessment, a plot of $50 \mathrm{~m} \times 50 \mathrm{~m}$ was laid randomly. Within this plot, trees, saplings and seedlings were sampled by laying ten quadrats of $10 \mathrm{~m} \times 10 \mathrm{~m}$; shrubs, 20 quadrats of $5 \mathrm{~m} \times 5 \mathrm{~m}$; and herbs, 20 quadrats of $1 \mathrm{~m} \times 1 \mathrm{~m}$ (refs 33-35). Circumference at breast height (cbh), i.e. $1.37 \mathrm{~m}$ and diameter at $10 \mathrm{~cm}$ from the base for each tree and seedling were recorded for considering individuals as trees $(\mathrm{cbh} \geq 31.5 \mathrm{~cm})$, saplings (cbh 10.5$31.4 \mathrm{~cm})$ and seedlings $(\mathrm{cbh}<10.5 \mathrm{~cm})$. Shrubs were considered as woody species having several branches arising from their base, and herbs were considered as those species having aerial parts surviving for one season, though their underground parts, i.e. roots/rhizomes/bulbs, etc. may remain alive during other seasons. From each site, samples of each species were collected and identified with the help of local and regional flora ${ }^{17-21}$.

The data collected during field surveys were analysed in MS-Excel following standard ecological methods ${ }^{36-38}$. 
Table 1. Site/habitat characteristics of Betula utilis populations in Hamta Pass area, Himachal Pradesh, India

\begin{tabular}{|c|c|c|c|c|c|c|c|}
\hline Site & Altitude (m) & Latitude (N) & Longitude (E) & Habitat & Slope $\left({ }^{\circ}\right)$ & Aspect & Community \\
\hline 1 & 3057 & $32^{\circ} 12^{\prime} 52.32^{\prime \prime}$ & $77^{\circ} 14^{\prime} 18.42^{\prime \prime}$ & Moist & 50 & NW & $\mathrm{BU}$ \\
\hline 2 & 3109 & $32^{\circ} 13^{\prime} 42.54^{\prime \prime}$ & $77^{\circ} 14^{\prime} 08.82^{\prime \prime}$ & Bouldery & 65 & NW & AP \\
\hline 3 & 3150 & $32^{\circ} 14^{\prime} 56.94^{\prime \prime}$ & $77^{\circ} 14^{\prime} 41.16^{\prime \prime}$ & Shady moist & 55 & SW & $\mathrm{AP}$ \\
\hline 4 & 3155 & $32^{\circ} 15^{\prime} 03.60^{\prime \prime}$ & $77^{\circ} 14^{\prime} 44.22^{\prime \prime}$ & Moist & 55 & NW & $\mathrm{BU}$ \\
\hline 5 & 3171 & $32^{\circ} 12^{\prime} 55.14^{\prime \prime}$ & $77^{\circ} 14^{\prime} 30.72^{\prime \prime}$ & Moist & 60 & NW & $\mathrm{BU}$ \\
\hline 6 & 3173 & $32^{\circ} 15^{\prime} 46.44^{\prime \prime}$ & $77^{\circ} 15^{\prime} 05.94^{\prime \prime}$ & Shady moist & 40 & W & $\mathrm{BU}$ \\
\hline 7 & 3190 & $32^{\circ} 15^{\prime} 41.46^{\prime \prime}$ & $77^{\circ} 14^{\prime} 59.40^{\prime \prime}$ & Moist & 30 & NW & QS \\
\hline 8 & 3230 & $32^{\circ} 14^{\prime} 58.92^{\prime \prime}$ & $77^{\circ} 14^{\prime} 45.84^{\prime \prime}$ & Moist & 60 & W & AA \\
\hline 9 & 3258 & $32^{\circ} 15^{\prime} 52.02^{\prime \prime}$ & $77^{\circ} 15^{\prime} 13.50^{\prime \prime}$ & Moist & 40 & NW & $\mathrm{BU}$ \\
\hline 10 & 3310 & $32^{\circ} 13^{\prime} 45.00^{\prime \prime}$ & $77^{\circ} 14^{\prime} 20.94^{\prime \prime}$ & Shady moist & 50 & W & QS \\
\hline 11 & 3317 & $32^{\circ} 13^{\prime} 02.58^{\prime \prime}$ & $77^{\circ} 14^{\prime} 54.78^{\prime \prime}$ & Moist & 35 & NW & $\mathrm{BU}$ \\
\hline 12 & 3364 & $32^{\circ} 13^{\prime} 18.60^{\prime \prime}$ & $77^{\circ} 14^{\prime} 55.74^{\prime \prime}$ & Shady moist & 40 & SW & $\mathrm{BU}$ \\
\hline 13 & 3411 & $32^{\circ} 15^{\prime} 46.26^{\prime \prime}$ & $77^{\circ} 15^{\prime} 25.08^{\prime \prime}$ & Rocky & 50 & W & $\mathrm{BU}$ \\
\hline 14 & 3505 & $32^{\circ} 13^{\prime} 45.78^{\prime \prime}$ & $77^{\circ} 14^{\prime} 35.34^{\prime \prime}$ & Bouldery & 60 & W & $\mathrm{BU}$ \\
\hline 15 & 3753 & $32^{\circ} 16^{\prime} 01.50^{\prime \prime}$ & $77^{\circ} 15^{\prime} 06.54^{\prime \prime}$ & Rocky & 40 & NW & $\mathrm{BU}$ \\
\hline 16 & 3760 & $32^{\circ} 15^{\prime} 57.06^{\prime \prime}$ & $77^{\circ} 15^{\prime} 01.92^{\prime \prime}$ & Rocky & 30 & SW & BU-PC \\
\hline
\end{tabular}

On the basis of importance value index (IVI), different communities were identified. Thereafter, data from different populations were pooled to calculate community averages in terms of density, total basal area (TBA) and Shannon-Wiener information index of species diversity $\left(H^{\prime}\right)^{39}$. The total count of species was considered as species richness. The diameter size class was employed to develop the population structure of tree species. Ten random size classes $(<10.5 \mathrm{~cm}$ for seedlings, $10.5-31.4 \mathrm{~cm}$ for saplings, 31.5-41.5, 41.6-51.5, 51.6-61.5, 61.6-71.5, $71.6-81.5,91.6-100.5$ and $>100 \mathrm{~cm}$ ) of individuals tree species were formed. The total number of individuals was calculated from each quadrate for each tree species and relative density was calculated as a percentage of total number of individuals in all size classes.

\section{Assessment of physico-chemical properties in B. utilis forests}

Soil samples were collected from each studied site within each plot of $50 \times 50 \mathrm{~m}(15-20 \mathrm{~cm}$ depth). Five soil samples, four from the corners and one from the centre of each plot were collected, pooled and mixed properly to make a composite sample. The air-dried soil samples were assessed for further tests and analysis. Soil $\mathrm{pH}$ was measured using a $\mathrm{pH}$ meter in $1: 5$ mixture of soil and distilled water, moisture content was recorded as \% difference in fresh and dry soil weight, \% organic carbon and organic matter were analysed as described by Walkley and Black method ${ }^{40}$, available nitrogen by kjeldahl method $^{41}$, available phosphorus by Olsen's extraction method $^{42}$ and available potassium by flame photometer ${ }^{43}$.

\section{Numerical and statistical analysis}

All numerical analysis was done in MS-Excel. Regression analysis was performed to estimate the relationship among altitude and ecological parameters. Pearson correlation coefficient was calculated between various ecological parameters and soil parameters using STATISTICA-8.

\section{Results and discussion}

\section{Site and habitat characteristics}

Totally 16 populations of $B$. utilis were assessed from different accessible aspects and habitats in the subalpine zone for status and distribution pattern. The studied sites were represented by four habitats, i.e. moist, shady moist, rocky and bouldery, and three aspects, i.e. northwest, west and southwest between $32^{\circ} 12^{\prime} 52.32^{\prime \prime}-$ $32^{\circ} 15^{\prime} 57.06^{\prime \prime} \mathrm{N}$ lat. and $77^{\circ} 14^{\prime} 18.42^{\prime \prime}-77^{\circ} 15^{\prime} 01.92^{\prime \prime} \mathrm{E}$ long. and 3047-3760 $\mathrm{m}$ amsl altitude. Table 1 shows the habitat characteristics. The dominant shady, moist and moist habitats were observed in mixed B. utilis forest, while the pure B. utilis stands were found in rocky and bouldery habitats. They formed large starches of monodominant forests in the NW aspect, and a discontinuous and abrupt treeline in the present study sites. In TransHimalaya treeline, B. utilis is dominant in the northfacing slope ${ }^{44}$. The soil receives moisture from seasonal snow on the hilltop and winter snow is the main source of moisture. The western- and south-western facing slopes are quite dry and B. utilis populations exist in scattered pockets. Soil moisture and aspect are the governing and controlling factors for $B$. utilis distribution in the subalpine zone of Manag valley, Nepal Himalaya. The northfacing slopes receive a small part of monsoon rainfall, therefore, snowmelt-water from the high mountains is the main source of soil moisture ${ }^{44}$.

\section{Floristic composition in B. utilis forests}

The field study was conducted in the subalpine zone of Hamta Pass, which is unexplored in terms of floristic 
Table 2. Associated life-forms of B. utilis forests in subalpine zone of Hamta Pass area

\begin{tabular}{lll}
\hline Trees & \multicolumn{1}{c}{ Shrubs } & \multicolumn{1}{c}{ Herbs } \\
\hline Abies pindrow & Clematis montata & Ainsliaea aptera \\
Acer acuminatum & Juniperus communis & Adiantum venustum \\
Betula utilis & Juniperus macropoda & Bistorta affine \\
Prunus cornuta & Lonicera parviflora & Anaphalis contorta \\
Quercus semecarpifolia & Rosa macrophylla & Angelica archangelica \\
& Rosa moschata & Angelica glauca \\
& Rosa sericia & Aquilegia pubiflora \\
& Salix denticulata & Caltha palustris \\
& Salix lindleyana & Dactylorhiza hatagirea \\
& Smilax vaginata & Delphinium brunonianum \\
& Vibernum mullah & Inula grandiflora \\
& & Polygonatum verticillaum \\
& & Polygonatum cirrhifolium \\
& & Sinopodophyllum hexandrum \\
& & Smilacina oleracea \\
& & Trillium govanianum \\
\hline
\end{tabular}

Table 3. Community-wise species richness, density, total basal area (TBA) and species diversity index of trees, shrubs and herbs in Hamta Pass area

\begin{tabular}{|c|c|c|c|c|c|c|c|c|c|}
\hline \multirow[b]{2}{*}{ Community } & \multirow[b]{2}{*}{$\begin{array}{c}\text { Site } \\
\text { representation }\end{array}$} & \multirow[b]{2}{*}{ Species richness } & \multirow[b]{2}{*}{$\begin{array}{c}\text { TBA } \\
\left(\mathrm{M}^{2} \mathrm{ha}^{-1}\right)\end{array}$} & \multicolumn{3}{|c|}{ Density } & \multicolumn{3}{|c|}{ Species diversity index $\left(H^{\prime}\right)$} \\
\hline & & & & $\begin{array}{c}\text { Trees } \\
\left(\text { ind } \mathrm{ha}^{-1} \text { ) }\right.\end{array}$ & $\begin{array}{l}\text { Shrubs } \\
\left(\text { ind } \mathrm{ha}^{-1} \text { ) }\right.\end{array}$ & $\begin{array}{l}\text { Herbs } \\
\text { (ind } \mathrm{m}^{2} \text { ) }\end{array}$ & Trees & Shrubs & Herbs \\
\hline AA & 1 & $36(3 \mathrm{~T}, 2 \mathrm{~S}, 1 \mathrm{H})$ & 17.22 & 260 & 420 & 33 & 0.9 & 0.7 & 3.3 \\
\hline AP & 2 & $55(4 \mathrm{~T}, 3 \mathrm{~S}, 48 \mathrm{H})$ & 42.10 & 250 & 420 & 29 & 0.8 & 1.1 & 3.5 \\
\hline BU & 10 & $127(5 \mathrm{~T}, 11 \mathrm{~S}, 111 \mathrm{H})$ & 17.36 & 226 & 508 & 27 & 0.9 & 2.1 & 4.2 \\
\hline QS & 2 & $45(2 \mathrm{~T}, 2 \mathrm{~S}, 41 \mathrm{H})$ & 6.94 & 160 & 515 & 25 & 0.7 & 0.6 & 3.3 \\
\hline BU-PC & 1 & $15(3 \mathrm{~T}, 1 \mathrm{~S}, 11 \mathrm{H})$ & 20.92 & 270 & 300 & 21 & 0.4 & 0.0 & 1.7 \\
\hline
\end{tabular}

T, Trees; S, Shrubs; H, Herbs.

composition. Total of 180 species representing five trees, 11 shrubs and 164 herbs was recorded. Table 2 presents the notable life forms (i.e. trees, shrubs and herbs) in the subalpine zone. The subalpine zone forms the transition zone between temperate and alpine zones. It is dominated by evergreen coniferous, and evergreen and deciduous broadleaved species. The species composition changes with increasing altitude, aspect, habitat and slope. The tree species richness (5) in the present study is similar to the treeline ecotone of Eastern ${ }^{45}$ and Central Nepal Himalaya $^{46}$.

\section{Community diversity, composition and structure}

A total of five tree communities namely, A. acuminatum, A. pindrow, B. utilis, Q. semecarpifolia and B. utilis$P$. cornuta mixed were recorded on the basis of IVI. Maximum ten sites were represented in B. utilis community, followed by two sites in $A$. pindrow and $Q$. semecarpifolia each and one site each in A. acuminatum and B. utilis $-P$. cornuta mixed communities (Table 3 ).

Among communities, the highest species richness, i.e. 127 was in B. utilis community, followed by $A$. pindrow
(55), Q. semecarpifolia (45), A. acuminatum (36) and $B$. utilis-P. cornuta mixed community (15) (Table 3 ). High species richness in pure $B$. utilis community might be due to decrease in canopy cover. Similar trends of species richness in pure $B$. utilis community have also been reported from Kedarnath Wildlife Sanctuary (KWS) ${ }^{47}$. The recorded species richness was higher than the earlier reported value from the Kumaun Himalaya ${ }^{24,48}$, Hirb and Shoja catchments of Himachal Pradesh ${ }^{33}$ and subalpine forests of $\mathrm{KWS}^{31}$. The highest species richness in the $B$. utilis community could be due to overlapping of species towards the centre from the highest and lowest elevations ${ }^{49}$. High forest density and forest cover in the subalpine zone, are a consequence of low light intensity under the forest canopy ${ }^{50}$. The scanty ground vegetation in subalpine forests is linked with decrease in temperature in this zone. The highest total tree density (270 individuals $\left.\mathrm{ha}^{-1}\right)$, shrub density (515 individuals $\mathrm{ha}^{-1}$ ) and herb density ( 33 individuals $\mathrm{m}^{-2}$ ) was contributed by $B$. utilis$P$. cornuta mixed, $Q$. semecarpifolia and A. acuminatum communities respectively (Table 3 ). The high tree density in B. utilis community might be due to low girth class ${ }^{47}$. The highest TBA was contributed by $A$. pindrow community $\left(42.10 \mathrm{~m}^{2} \mathrm{ha}^{-1}\right)$, followed by $B$. utilis $-P$. cornuta 


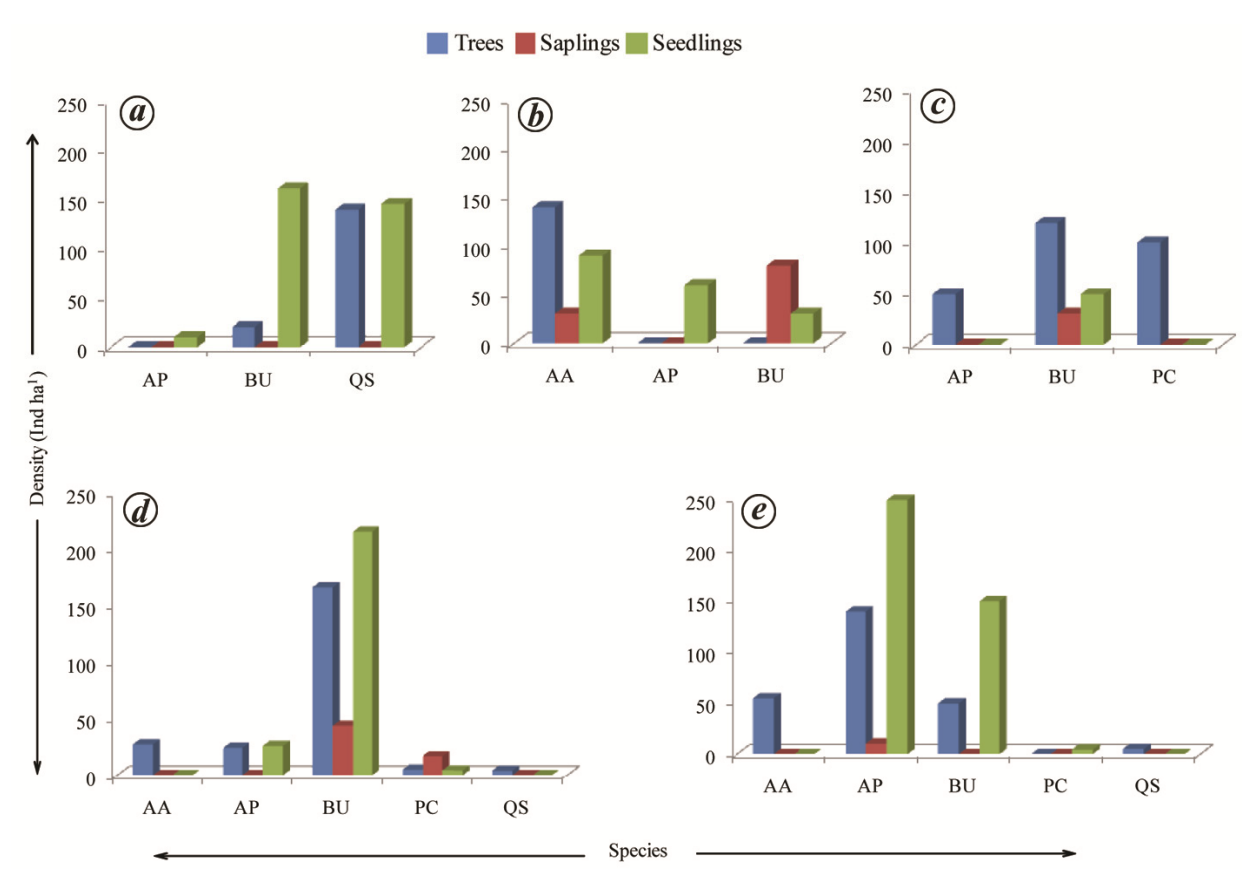

Figure 2. Regeneration status of trees in the identified communities based on the density of trees, saplings and seedlings of the species. a, Quercus semecarpifolia community. b, Acer acuminatum community. c, Betula utilis community. d, Betula utilis-Prunus cornuta mixed community. $\boldsymbol{e}$, Abies pindrow community.

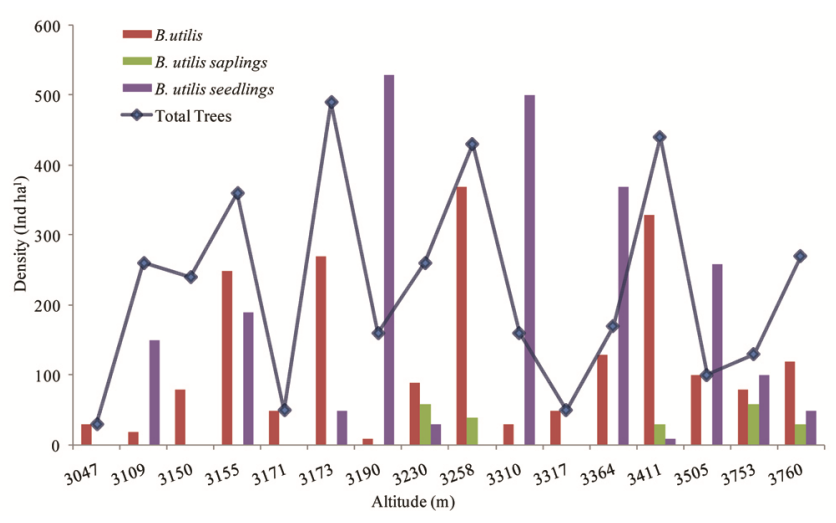

Figure 3. Altitude-wise density of B. utilis trees, saplings and seedlings.

$\left(20.92 \mathrm{~m}^{2} \mathrm{ha}^{-1}\right)$ mixed, B. utilis $\left(17.36 \mathrm{~m}^{2} \mathrm{ha}^{-1}\right)$, A. acuminatum $\left(17.22 \mathrm{~m}^{2} \mathrm{ha}^{-1}\right)$ and pure $Q$. semecarpifolia $\left(6.94 \mathrm{~m}^{2} \mathrm{ha}^{-1}\right)$ communities respectively (Table 3$)$. TBA with increasing altitude showed discontinuous pattern and was maximum at higher elevation. Along with increasing altitude, the growth of trees was stunted and small with lower girth class. TBA and density for trees and shrubs were comparable to earlier studies from temperate and subalpine forests in $\operatorname{IHR}^{27,28,31,32,48,51,52}$.

\section{Species diversity}

Community-wise highest species diversity index $\left(H^{\prime}\right)$ for trees was recorded in B. utilis and A. acuminatum com- munities ( 0.9 each), followed by A. pindrow (0.8), Q. semecarpifolia mixed (0.7) and B. utilis $-P$. cornuta mixed (0.4) communities. The highest $H^{\prime}$ for shrubs (2.1) was recorded for $B$. utilis community and lowest in $B$. utilis$P$. cornuta mixed (nil) community. The highest $H^{\prime}$ diversity for herbs was recorded in B. utilis (4.2) community, followed by A. pindraw (3.5), A. acuminatum and $Q$. semecarpifolia (3.3) pure communities and B. utilis-P. cornuta mixed (1.7) communities (Table 3). The $H^{\prime}$ values are comparable with those of the earlier studies from temperate and subalpine forests $\mathrm{s}^{24,26,32,33,48,51,52}$.

\section{Regeneration pattern of trees in forest communities}

Figure $2 a-e$ shows the regeneration pattern of trees in the identified communities. The regeneration of B. utilis varied with community. Regeneration pattern was observed on the basis of seedlings and saplings density in the forest communities. The regeneration of dominant species in B. utilis community was highest, particularly in sapling layer. Regeneration of dominant species in $Q$. semecarpifolia, B. utilis-P. cornuta mixed and A. pindrow communities was highest only in terms of seedling layer. While poor regeneration of dominant species was recorded in A. acuminatum and B. utilis pure communities. The poor recruitment of seedlings and establishment of saplings of dominant species in the recorded communities may be due to high tree canopy coverage and lack of microhabitat, high litter accumulation and low light availability affecting the seed germination of $B . u_{i l i s}{ }^{53}$. 


\section{Altitude-wise regeneration of $B$. utilis}

Discontinuous pattern of B. utilis trees, saplings and seedlings density was observed along with increasing altitude (Figure 3). The maximum studied B. utilis population was recorded with zero sapling density. The gap in the distribution of $B$. utilis seedlings and saplings might be due to high heterogeneity. Other factors responsible for the discontinuous recruitment of seedlings and saplings may be high canopy cover and aspect ${ }^{46}$. Absence of seedlings density in the southwest and west aspects also supports the fact that aspect plays a crucial role in species distribution. In Hamta Pass, the habitat of B. utilis in the southwest and west slopes was shady moist due to high canopy coverage ${ }^{54}$.

Regression analysis on density patterns of total trees, B. utilis, saplings and seedlings did not show uniform pattern with increasing altitude. The total tree density and $B$. utilis density decreased with increasing altitude due to monodominant forest of $B$. utilis and scanty distribution of the species in the subalpine zone of Hamta Pass (Figure 4). The density of total trees, B. utilis and seedlings along the altitude was statistically non-significant at $P \leq 0.05$ (Figure $5 a-c$ ). However, increase in saplings density along the altitude was statistically significant at $P \leq 0.05$ (Figure $5 d$ ). Along the increasing elevation, shrubs and herbs density pattern was also statistically non-significant at $P \leq 0.05$. The maximum density for both shrubs and herbs was found between 3100 and $3400 \mathrm{~m}$ amsl (Figure $5 e$ and $f$ ), this may be due to longer distance from pasture land and less disturbance of livestock grazing pressure. In general, herb density increases with increase in elevation; but in the upper subalpine zone of Hamta Pass, assessment was done in August when the area was highly exploited by overgrazing, especially the herb layer that might be the reason for decreasing density with increasing altitude. Also, altitude plays an important role in species distribution and allows specific species to grow.

It was assumed that soil moisture availability affects the regeneration of species in subalpine forests ${ }^{55}$. However, inadequate soil moisture might be responsible for seed germination and recruitment of seedlings and saplings in the Hamta Pass areas, as there are no glaciers. In the treeline ecotone, glaciated snow retreat is the main source of soil moisture content. Seedlings are more sensitive to moisture deficiency than deep-rooted mature plants $^{56}$, which might be attributed to slow initial growth $^{57}$. Seeds are extremely light-weight $(0.209 \pm$ $0.019 \mathrm{mg})^{58}$ and are dispersed by wind. Bryophyte mats (mosses) are an excellent substrate for seed germination and establishment due to their high moisture storage capacity; bryophyte mats act as a seed-trapper. However, litter is unfavourable for germination and establishment of B. utilis seeds ${ }^{53}$. Thus, lack of suitable microhabitat for seed germination and adverse climatic conditions (i.e. avalanche, snowdrift, low temperature, etc.) and anthropogenic pressures (i.e. overgrazing, camping and hiking) might be responsible for lower recruitment and establishment of seedlings in the subalpine zone of Hamta Pass. However, upward shift in B. utilis was not observed in Hamta Pass.

\section{Size class distribution of tree species in B. utilis forests}

The population structures of all tree species, except $A$. acuminatum exhibited similar trends (Figure 4). High accumulation of seedlings and saplings of $Q$. semecarpifolia, B. utilis and A. pindrow is the characteristic of subalpine forests in Hamta Pass. A. acuminatum showed higher accumulation towards tree size class with absence of seedlings and saplings. While $P$. cornuta showed higher accumulation in tree size class more than $100 \mathrm{~cm}$. The sufficient seedlings, saplings and young trees in any population indicate good regeneration status ${ }^{59}$. The environmental conditions in the subalpine zone do not permit many species to regenerate. However, treeline ecosystem is more sensitive to climate change and is responsible for the variations in distribution, growth pattern and seedbased regeneration of species across the treeline ${ }^{60}$. In particular reference to the regeneration of $B$. utilis, the growth of seedlings, saplings and young trees is ambient and resembles reverse $J$-shaped trends, showing good regeneration in the present study sites (Figure 4).

\section{Soil properties in B. utilis forest}

The edaphic factors, moisture content and nutrients are required for the survival of most of the species. Figure 6 presents altitude-wise soil results. The soil $\mathrm{pH}$ was slightly acidic in nature in birch forests across all elevations. Spatial variations in soil properties in forests are

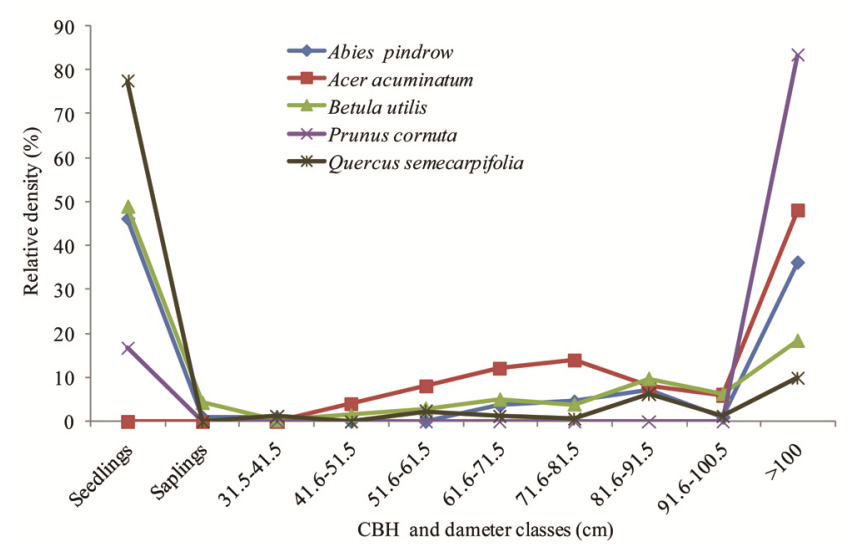

Figure 4. Population structure of associated tree species of B. utilis in Hamta Pass area, Himachal Pradesh. 
Table 4. Pearson's correlation coefficient $(n=16)$ between ecological attributes and soil parameters. Only significant values at $<0.05$ for parameters are shown in the table

\begin{tabular}{llr}
\hline Characteristics & \multicolumn{1}{c}{ Attributes } & Correlation coefficient $(r)$ \\
\hline Altitude & B. utilis saplings density & 0.52 \\
& Herb concentration of dominance & 0.54 \\
& Electrical conductivity & 0.52 \\
& Organic carbon and organic matter & -0.61 \\
Total tree density & Available potassium & 0.66 \\
& B. utilis trees density & 0.84 \\
B. utilis trees density & Trees concentration of dominance & 0.73 \\
Saplings density & Trees concentration of dominance & 0.69 \\
& Trees diversity & -0.59 \\
& pH & 0.57 \\
Herbs density & Available potassium & 0.55 \\
& Herbs concentration of dominance & -0.76 \\
& Electrical conductivity & 0.73 \\
& Organic carbon and organic matter & 0.59 \\
Moisture content & Available potassium & -0.57 \\
Electrical conductivity & Electrical conductivity & 0.63 \\
Organic carbon and matter & Organic carbon and organic matter & -0.60 \\
& Available soil nitrogen & -0.58 \\
& Available soil potassium & -0.70 \\
\hline
\end{tabular}
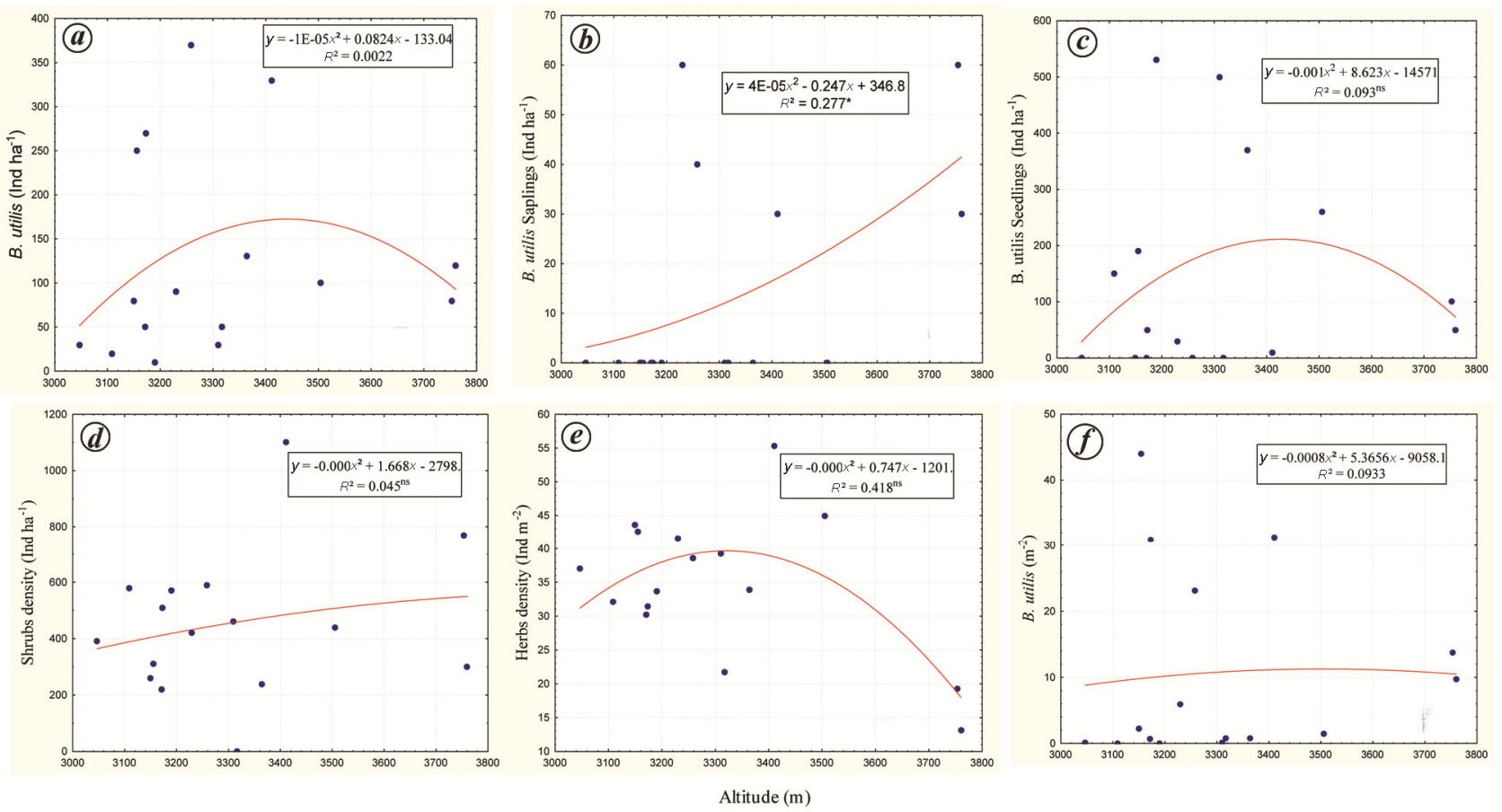

Figure 5. Density distribution pattern of (a) B. utilis, (b) saplings, (c) seedlings, $(\boldsymbol{d})$ shrubs, $(\boldsymbol{e})$ herbs and ( $\boldsymbol{f})$ total basal area (TBA) of B. utilis versus altitude.

mainly due to the rooting pattern and litter accumulation of the perennial vegetation ${ }^{61}$. The acidic $\mathrm{pH}$ in $B$. utilis forest was also reported in subalpine region of Nepal Himalaya $^{38}$. High litter decomposition and organic matter decrease $\mathrm{pH}$ in forests ${ }^{62}$. However, $\mathrm{pH}$ range from 5.5 to 6.5 is satisfactory for the growth of most of the plant species $^{63}$. Electrical conductivity (EC) and available potassium showed an increase with increasing altitude
$(P<0.05)$, while organic carbon and organic matter significantly decreased (Table 4$)$. No significant correlation was observed in moisture content with elevation. But, slight increase in moisture content with elevation might be due to decrease in temperature and increase in tree canopy cover (Figure 6) ${ }^{38}$. Soil moisture and temperature are limiting and controlling factors for the significant variation in topographical characters and vegetation 


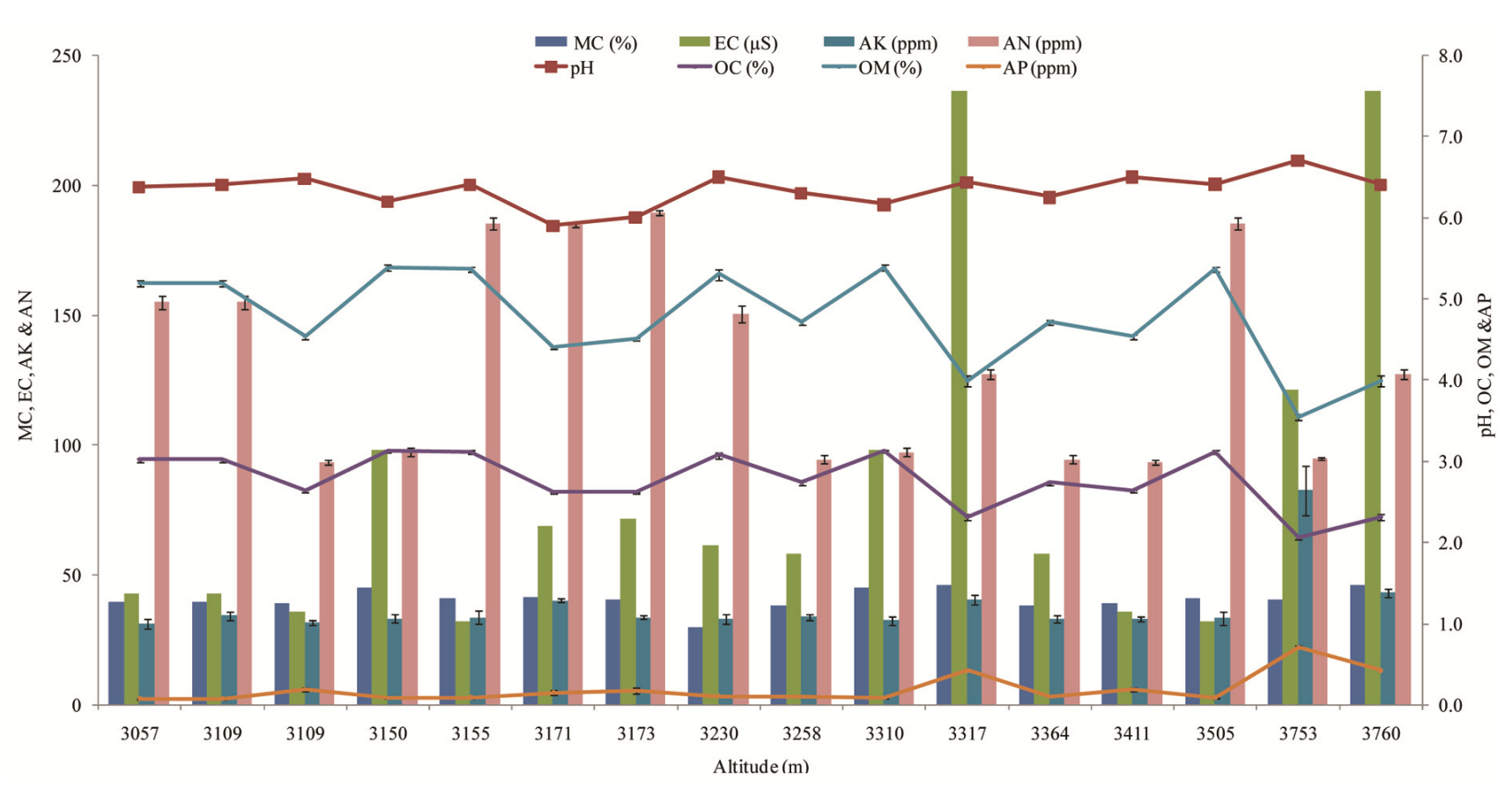

Figure 6. Altitude-wise soil characteristics of B. utilis populations. Mean value $(n=3)$ with standard error bar.

Table 5. Physico-chemical properties of soil in the studied sites of B. utilis

\begin{tabular}{lcccccccc}
\hline Community & MC $(\%)$ & $\mathrm{pH}$ & $\mathrm{EC}(\mu \mathrm{S})$ & $\mathrm{OC}(\%)$ & $\mathrm{OM}(\%)$ & $\mathrm{AP}(\mathrm{ppm})$ & AK $(\mathrm{ppm})$ & AN $(\mathrm{ppm})$ \\
\hline AA & 29.7 & 6.5 & 61.2 & 3.07 & 5.298 & 0.099 & 32.973 & 150.267 \\
AP & 39.0 & 6.4 & 39.4 & 2.8 & 4.9 & 0.1 & 32.9 & 124.1 \\
BU & 40.3 & 6.4 & 88.4 & 2.6 & 4.5 & 0.3 & 42.2 & 117.1 \\
QS & 39.7 & 6.4 & 63.9 & 2.7 & 4.7 & 0.2 & 37.5 & 120.6 \\
BU-PC & 46.1 & 6.4 & 236.0 & 2.310 & 3.982 & 0.420 & 42.912 & 127.167 \\
\hline
\end{tabular}

MC, Moisture content; EC, Electrical conductivity; OC, Organic carbon; OM, Organic matter; AP, Available phosphorus; AK, Available potassium; AN, Available nitrogen.

stands structure and physiognomy of species in treeline ${ }^{55}$. Available $\mathrm{P}$ ranged from 0.07 to $0.71 \mathrm{ppm}$, available $\mathrm{K}$ from 31 to $82.37 \mathrm{ppm}$ and available $\mathrm{N}$ from 93.33 to $189.40 \mathrm{ppm}$ (Figure 6). Positive significant correlation was observed between moisture content and EC. Soil EC depends on the availability and mobility of ions. The concentration of ions in the soil increases with increase in moisture content and thereby a significant increase in $\mathrm{EC}^{64}$. Negative significant correlation was observed between EC and organic carbon and organic matter. The organic matter also showed negative correlation with available soil nitrogen and potassium (Table 4).

Table 5 shows community-wise soil parameters. The highest moisture content $(46.1 \%)$ and EC $(236 \mu \mathrm{S})$ were recorded in $B$. utilis $-P$. cornuta mixed and A. acuminatum pure communities. Organic carbon $(3.1 \%)$ and organic matter $(5.3 \%)$ were maximum in A. acuminatum, followed by $A$. pindrow, $Q$. semecarpifolia, B. utilis and B. utilis-P. cornuta mixed communities. Whereas availa- ble phosphorus and potassium were maximum in $B$. utilis- $P$. cornuta mixed forest followed by $B$. utilis pure forest with least recorded in $A$. acuminatum and $A$. pindrow communities. The highest available nitrogen (150.3 ppm) was recorded in A. acuminatum community. Community type may contribute in determining the nutrients cycling in forest ecosystems because of canopy complexity in the mixed forests. The canopy complexity might be responsible for nutrient production and availability. It also produces heterogeneity of soil nutrients in the mixed forest ${ }^{65}$. According to Vesterdal et al. ${ }^{66}$ tree species can also be considered as an indicator of soil carbon and nitrogen. Deciduous species have larger forest floor than other forest species for carbon accumulation ${ }^{67}$. Shedayi et $a l .{ }^{68}$ reported that soil total carbon (STC) and soil total nitrogen (STN) were highest in B. utilis forest, and highlighted the significant impact of vegetation type and litter on STC and STN, while there was no impact of altitude and herbaceous biomass on carbon and nitrogen concentration in the soil. 

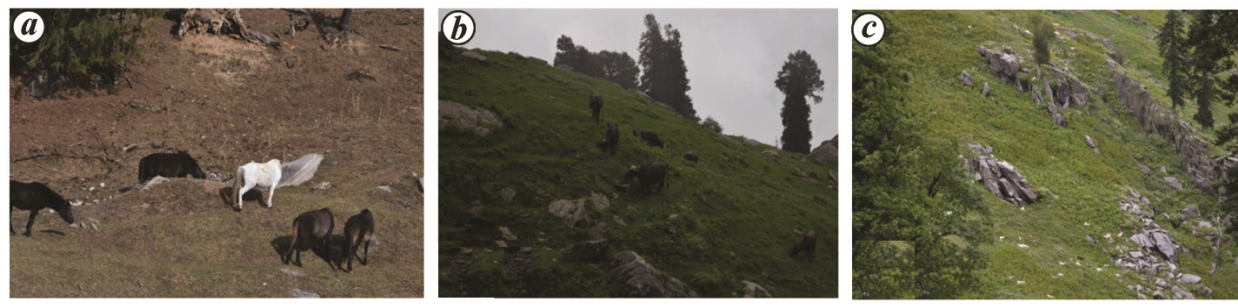

Figure 7. Livestock grazing pressure in Hamta Pass area.

\section{Herbivory and anthropogenic pressure on treeline in Hamta Pass area}

The anthropogenic activities such as overgrazing, tourism, trampling and camping cause loss of biodiversity. The grazing pressure by livestock (i.e. horse, buffalo and sheep) on subalpine and alpine mats was high (Figure 7). Overexploitation of trees and shrubs for fuel and fodder by the migrants during grazing season affect growth and development of tree species in the subalpine zone. Economically important species such as Trillium govanianum, Angelica glauca and Dactylorhiza hatagirea are extracted by the herdsmen and local inhabitants, which also causes a decrease in the population of species.

\section{Conclusion and recommendations}

The present study shows floristic richness represented by a total of 188 species of trees, shrubs and herbs distributed over four habitats and three aspects. The populations of the B. utilis were dominated by B. utilis, A. acuminatum, $A$. pindrow, Prunus cornuta and $Q$. semecarpifolia. The spatial heterogeneity pattern of saplings and seedlings of dominant tree species was recorded in different community structures. With discontinuous and abrupt treeline; $B$. utilis was the dominant treeline-forming species in Hamta Pass. Overexploitation, deforestation, overgrazing and natural calamities such as erosion, snow drift, forest fires and landslides might be important factors responsible for the recruitment and establishment of seedlings and saplings in the study area. The density and regeneration (i.e. seedlings and saplings) of $B$. utilis in most of the populations revealed that this species will continue to grow in the study area in future as used. However, the continued anthropogenic activities, climate change and other natural factors may cause population depletion in the area. Frequent monitoring of the populations representing $B$. utilis would help in understanding the dynamics of the vegetation and impact of anthropogenic activities, impact of climatic and non-climatic factors on population, and identification of microhabitats for seed germination which may strengthen the conservation and sustainability of $B$. utilis in the near future. Thus, the present study would form the baseline to suggest strategies for the conservation of B. utilis populations in natural habitats.
1. Myers, N., Mittermeier, R. A., Mittermeier, C. G., da Fonseca, G. A. B. and Kent, J., Biodiversity hotspots for conservation priorities. Nature, 2000, 403, 853-858.

2. Gentry, A. H., Patterns of diversity and floristic composition in neotropical montane forests. In Proceedings of the Neotropical Montane Forest Biodiversity and Conservation Symposium, New York Botanical Garden, 21-26 June 1993.

3. Hajra, P. K. and Rao, R. R., Distribution of vegetation types in northwest Himalaya with brief remarks on phytogeography and floral resource conservation. Proc. Plant Sci., 1990, 100(4), 263-277.

4. Samant, S. S., Assessment, evaluation and conservation prioritization of floristic diversity in the Trans, North West and Western Himalaya. D.Sc. thesis, Kumaon University, Nainital, 2015.

5. Dhar, U., Prioritization of conservation sites in the timberline zone of west Himalaya. In Setting Biodiversity Conservation Priorities for India (eds Singh, S. et al.), World Wide Fund for Nature, New Delhi, 2000, pp. 193-211.

6. Shaheen, H., Ullah, Z., Khan, S. M. and Harper, D. M., Species composition and community structure of western Himalayan moist temperate forests in Kashmir. For. Ecol. Manage., 2012, 278, $138-145$.

7. Chawla, A., Rajkumar, S., Singh, K. N., Lal, B., Thukral, A. K. and Singh, R. D., Plant species diversity along an altitudinal gradient of Bhabha Valley in Western Himalaya. J. Mt. Sci., 2008, $\mathbf{5}(2), 157-177$.

8. IUCN, IUCN Red List of Threatened Species, International Union for Conservation of Nature (IUCN), Gland, Switzerland, 2003.

9. Pant, S. and Samant, S. S., Diversity and regeneration status of tree species in Khokhan Wildlife Sanctuary, North Western Himalaya. Trop. Ecol., 2012, 53(3), 317-331.

10. Busing, R. T., White, P. S. and Mackenzie, M. D., Gradient analysis of old spruce-fir forest of the Great Smokey Mountains. Can. J. Bot., 1993, 71(7), 951-958.

11. Sakai, A. and Larcher, W., Frost Survival of Plants: Responses and Adaptation to Freezing Stress, Springer Science \& Business Media, 2012, vol. 62.

12. Chauhan, N. S., Medicinal and Aromatic Plants of Himachal Pradesh, Indus Publishing, New Delhi, 1999.

13. Selvam, A. B. D., Inventory of vegetable crude drug samples housed in Botanical Survey of India, Howrah. Pharmacogn. Rev., 2008, 2(3), 61-94.

14. Shukla, S., Mishra, T., Pal, M., Meena, B., Rana, T. S. and Upreti, D. K., Comparative analysis of fatty acids and antioxidant activity of Betula utilis bark collected from different geographical regions of India. Free Radic. Antioxid., 2017, 7(1), 80-85.

15. Kumaraswamy, M. V., Kavitha, H. U. and Satish, S., Antibacterial evaluation and phytochemical analysis of Betula utilis D. Don against some human pathogenic bacteria. Adv. Biol. Res., 2008, 2(1-2), 21-25.

16. Mishra, T. et al., Isolation, characterization and anticancer potential of cytotoxic triterpenes from Betula utilis bark. PLoS ONE, 2016, 11(7), e0159430.

17. Polunin, O. and Stainton, A., Flowers of the Himalaya, Oxford University Press, Delhi, India, 1984. 
18. Chowdhery, H. J. and Wadhwa, B. M., Flora of Himachal Pradesh, Vols 1-3, Botanical Survey of India, Calcutta, 1984.

19. Dhaliwal, D. S. and Sharma, M., Flora of Kullu District (Himachal Pradesh), Bishen Singh Mahendra Pal Singh, Dehradun, 1999.

20. Singh, S. K. and Rawat, G. S., Flora of Great Himalayan National Park, Himachal Pradesh, Bishen Singh Mahendra Pal Singh, Dehradun, 2000.

21. Khullar, S. P., An Illustrated Fern Flora of the West Himalaya, Vol. II, International Book Distributors, Dehradun, 2000.

22. Singh, H. and Sharma, M., Flora of Chamba District (Himachal Pradesh), Bishen Singh Mahender Pal Singh, Dehradun, 2006.

23. Kalakoti, B. S., Pangtey, Y. P. S. and Saxena, A. K., Quantitative analysis of high altitude vegetation of Kumaun Himalaya. $J$. Indian Bot. Soc., 1986, 65, 384-396.

24. Adhikari, B. S., Rikhari, H. C., Rawat, Y. S. and Singh, S. P., High altitude forest: composition diversity and profile structure in a part of Kumaun Himalaya. Trop. Ecol., 1991, 32(1), 86-97.

25. Bhandari, B. S. and Tiwari, S. C., Dominance and diversity along an altitudinal gradient in a montane forest of Garhwal Himalaya. Proc. Indian Natl. Sci. Acad., 1997, 63(6), 639-646.

26. Joshi, H. C. and Samant, S. S., Assessment of forest vegetation and conservation priorities of communities in a part of Nanda Devi Biosphere Reserve, West Himalaya. Part 1. Int. J. Sustain. Dev. World Ecol., 2004, 11(3), 326-336.

27. Samant, S. S. and Joshi, H. C., Floristic diversity, community patterns and changes of vegetation in Nanda Devi National Park. In Biodiversity Monitoring Expedition Nanda Devi, Bishen Singh Mahendra Pal Singh, Dehradun, 2004, pp. 39-54.

28. Joshi, H. C. and Samant, S. S., Change in structural and compositional diversity with altitude: a study from Nanda Devi Biosphere Reserve (NDBR), West Himalaya, India. Indian J. For., 2014, 37(2), 121-136.

29. Pant, S. and Samant, S. S., Population ecology of the endangered Himalayan yew in Khokhan Wildlife Sanctuary of North Western Himalaya for conservation management. J. Mt. Sci., 2008, 5(3), 257-264.

30. Chawla, A., Rajkumar, S., Singh, K. N., Lal, B., Singh, R. D. and Thukral, A. K., Plant species diversity along an altitudinal gradient of Bhabha Valley in western Himalaya. J. Mt. Sci., 2008, $\mathbf{5}, 157-177$.

31. Gairola, S., Rawal, R. S. and Todaria, N. P., Forest vegetation patterns along an altitudinal gradient in sub-alpine zone of West Himalaya, India. Afr. J. Plant Sci., 2008, 2(6), 42-48.

32. Rana, M. S. and Samant, S. S., Prioritization of habitats and communities for conservation in the Indian Himalayan Region: a stateof-the-art approach from Manali Wildlife Sanctuary. Curr. Sci., 2009, 97(3), 326-335.

33. Sharma, A. and Samant, S. S., Diversity, structure and composition of forest communities in Hirb and Shoja Catchments of Himachal Pradesh, North West Himalaya, India. Int. J. Bot., 2013, 9(1), 50-54.

34. Dhar, U., Rawal, R. S. and Samant, S. S., Structural diversity and representativeness of forest vegetation in a protected area of Kumaun Himalaya, India. Implications for conservation. Biodivers. Conserv., 1997, 6, 1045-1062.

35. Joshi, H. C. and Samant, S. S., Assessment of forest vegetation and conservation priorities of communities in part of Nanda Devi Biosphere Reserve, West Himalaya. Part I. Int. J. Sustain. Dev. World Ecol., 2004, 11(3), 326-336.

36. Curtis, J. T. and McIntosh, The interrelation of certain analytic and phytosociological characters. Ecology, 1950, 31, 434-455.

37. Greig-Smith, P., Quantitative Plant Ecology, Academic Press, New York, USA, 1957.

38. Mueller-Dombois, D. and Ellenberge, H., Aims and Methods of Vegetation Ecology, John Willey, New York, USA, 1974.
39. Pielou, E. C., Ecological Diversity, John Wiley, New York, USA, 1975.

40. Walkley, A. and Black, I. A., An examination of the Degtjareff method for determining soil organic matter and a proposed modification of the chromic soil titration method. Soil Sci., 1934, 37, 29-37.

41. Subbiah, B. V. and Asiija, G. L., A rapid procedure for the estimation of nitrogen in soil. Curr. Sci., 1956, 25, 259-260.

42. Olsen, S. R., Cole, C. V., Watanabe, F. S. and Dean, L. A., Estimation of Available Phosphorus in Soils by Extraction with Sodium Bicarbonate, US Government Print Office, Washington, USA, 1954, p. 19.

43. Jackson, M. L., Soil Chemical Analysis, Prentice-Hall, London, UK, 1958.

44. Shrestha, B. B., Ghimire, B., Lekhak, H. D. and Jha, P. K., Regeneration of treeline birch (Betula utilis D. Don) forest in a transHimalayan dry valley in central Nepal. Mt. Res. Dev., 2007, 27(3), 259-267.

45. Bhuju, D. R., Carrer, M., Gaire, N. P., Soraruf, L., Riondato, R., Salerno, F. and Maharjan, S. R., Dendroecological study of high altitude forest at Sagarmatha National Park, Nepal. Nepal J. Sci. Technol., 2010, 119-130.

46. Gaire, N. P., Dhakal, Y. R., Lekhak, H. C., Bhuju, D. R. and Shah, S. K., Vegetation dynamics in treeline ecotone of Langtang National Park, Central Nepal. Nepal J. Sci. Technol., 2010, 11, $107-114$.

47. Rai, I. D., Adhikari, B. S., Rawat, G. S. and Bargali, K., Community structure along timberline ecotone in relation to microtopography and disturbances in western Himalaya. Not. Sci. Biol., 2012, 4(2), 41-52.

48. Bankoti, N. S., Rawal, R. S., Samant, S. S. and Pangtey, Y. P. S., Forest vegetation of inner hill ranges in Kumaun, central Himalaya. Trop. Ecol., 1992, 33(1), 41-53.

49. Colwell, R. K. and Hurtt, G. C., Nonbiological gradients in species richness and a spurious Rapoport effect. Am. Nat., 1994, 144, 570-595.

50. Jiangming, M. A. L., Shirong, S., Zuomin, Z., Yuandong, K. and Baoyu, C., Changes in species composition and diversity in the restoration process of subalpine dark brown coniferous forests in western Sichuan Province, China. Front. Biol. China, 2008, 3, 300-307.

51. Singh, A. and Samant, S. S., Conservation prioritization of habitats and forest communities in the Lahaul valley of proposed Cold Desert Biosphere Reserve, North Western Himalaya, India. Appl. Ecol. Environ. Res., 2010, 8(2), 101-117.

52. Samant, S. S., Joshi, H. C., Arya, S. C. and Pant, S., Studies on the structure, composition and changes of vegetation in Nanda Devi Biosphere Reserve of west Himalaya. Final Technical Report, Ministry of Environment and Forests, Government of India, 2002.

53. Bürzle, B. et al., Phytosociology and ecology of treeline ecotone vegetation in Rolwaling Himal, Nepal. Phytocoenologia, 2017, 47(2), 197-220.

54. Carlton, G. C. and Bazzaz, F. A., Regeneration of three sympatric birch species on experimental hurricane blowdown microsites. Ecol. Monogr., 1998, 68(1), 99-120.

55. Müller, M., Schwab, N., Schickhoff, U., Böhner, J. and Scholten, T., Soil temperature and soil moisture patterns in a Himalayan alpine treeline ecotone. Arct. Antarct. Alp. Res., 2016, 48(3), 501521.

56. Lazarus, B. E., Castanha, C., Germino, M. J., Kueppers, L. M. and Moyes, A. B., Growth strategies and threshold responses to water deficit modulate effects of warming on tree seedlings from forest to alpine. J. Ecol., 2018, 106(2), 571-585.

57. Wieser, G., Holtmeier, F. K. and Smith, W. K., Treelines in a changing global environment. In Trees in a Changing Environment, Springer, Dordrecht, The Netherlands, 2014, pp. 221-263. 
58. Wang, J. et al., Variation in seed germination of 86 subalpine forest species from the eastern Tibetan Plateau: phylogeny and life-history correlates. Ecol. Res., 2012, 27(2), 453-465.

59. Saxena, A. K. and Singh, J. S., Tree population structure of certain Himalayan forest associations and implications concerning their future composition. Vegetatio, 1984, 58(2), 61-69.

60. Schickhoff, U. et al., Do Himalayan treelines respond to recen climate change? An evaluation of sensitivity indicators. Earth Syst. Dyn., 2015, 6, 245-265.

61. Singh, J. S., Tiwari, A. K. and Saxena, A. K., Himalayan forests: a net source of carbon to the atmosphere. Environ. Conserv., 1985, 12, 67-69.

62. Biswas, T. D. and Mukherjee, S. K., Text Book of Soil Sciences, Tata McGraw-Hill, New Delhi, 1994, 2nd edn.

63. Brady, N. C. and Well, R. R., The Nature and Properties of Soil, MacMillan Press, New York, USA, 1984.

64. Brevik, E. C., Fenton, T. E. and Lazari, A., Soil electrical conductivity as a function of soil water content and implications for soil mapping. Precis. Agric., 2006, 7(6), 393-404.

65. Prescott, C. E., The influence of the forest canopy on nutrient cycling. Tree Physiol., 2002, 22(15-16), 1193-1200.
66. Vesterdal, L., Ritter, E. and Gundersen, P., Change in soil organic carbon following afforestation of former arable land. For. Ecol. Manage., 2002, 169(1-2), 137-147.

67. Oostra, S., Majdi, H. and Olsson, M., Impact of tree species on soil carbon stocks and soil acidity in southern Sweden. Scand. J. For. Res., 2006, 21(5), 364-371.

68. Shedayi, A. A., Xu, M., Naseer, I. and Khan, B., Altitudinal gradients of soil and vegetation carbon and nitrogen in a high altitude nature reserve of Karakoram ranges. Springer Plus, 2016, 5(1), 320 .

ACKNOWLEDGEMENTS. We thank the Director, G.B. Pant National Institute of Himalayan Environment, Almora for encouragement and providing the necessary facilities and Nidhi Kanwar for preparing the map of the study area. Financial assistance received from Ministry of Environment, Forest and Climate Change, Government of India through the National Mission on Himalayan Studies (NMHS) is acknowledged.

doi: $10.18520 / \mathrm{cs} / \mathrm{v} 120 / \mathrm{i} 5 / 872-882$ 